\begin{tabular}{|c|c|c|}
\hline $\begin{array}{l}\text { ISSN: 0001-5113 } \\
\text { AADRAY }\end{array}$ & $\begin{array}{c}\text { ACTA ADRIAT., } \\
\text { 58(2): } 359 \text { - 364, } 2017\end{array}$ & SHORT COMMUNICATION \\
\hline
\end{tabular}

\title{
New data on Pinctada radiata (Leach, 1814) (Bivalvia: Pteriidae) in the Adriatic Sea
}

\author{
Slavica PETOVIĆ ${ }^{*}$ and Vesna MAČIĆ ${ }^{1}$ \\ University of Montenegro, Institute of Marine Biology, Dobrota bb, 85330 Kotor, Montenegro \\ *Corresponding author: kascelanslavica@gmail.com
}

The first recorded population of Pinctada radiata in the Adriatic Sea was observed on the pier in Porto Montenegro marina (Tivat, Montenegro), in August 2016. Numerous individuals inhabited pier walls at a depth of $5 \mathrm{~m}$. The shell height (SH) values for the 15 randomly collected individuals of P. radiata ranged between $32.2 \mathrm{~mm}$ and $52.1 \mathrm{~mm}$ with an average $S H$ value of $38.3 \mathrm{~mm}$ (standard deviation \pm 6.1 ). Further surveys in Montenegro will provide information on the establishment of the observed population and what is its impact on local biodiversity.

Key words: alien species, Pinctada radiata, morphometric parameters, Adriatic Sea

\section{INTRODUCTION}

Pinctada radiata (Leach, 1814) known as 'pearl oyster', is widespread in shallow waters of the tropical and subtropical continental shelf regions and particularly abundant in the IndoPacific (WADA \& TËMKIN, 2008). Shell morphology of this species varies with salinity, usually is up to $50-65 \mathrm{~mm}$ but could exceed $100 \mathrm{~mm}$ in length and it is protandric hermaphrodite species with sex inversion occurring in shells $32-57 \mathrm{~mm}$ (ZENETOS et al.,. 2003). Furthermore, it is one of three alien species from family Pteriidae spread in the Mediterranean Sea. Other two species are Pinctada margaritifera (Linné, 1758) and Electroma vexillum (Reeve, 1857) (ÇEVIK et al.,, 2005; ZENETOS et al.,. 2010).

Pinctada radiata is considered as the first lessepsian bivalve species reported for the Mediterranean Sea, being described from Egypt in 1884 under the synonym Meleagrina savignyi (MONTEROSATO, 1878). Since then the species has successfully spread throughout the Mediterranean Sea, colonizing new habitats and becoming very abundant in the Levantine Sea, Greece, Libya, Turkey, Syria, Tunisia, Malta and France (DEIDUN et al.,. 2014). It was also intentionally imported for mariculture in many areas of Greece and Italy during the last century (KATSANEVAKIS et al.,. 2008). For better understanding on biometric, reproductive, demographic and genetic features of this bivalve species several detailed studies on the Mediterranean populations of $P$. radiata were performed in Tunisia (TLIG-ZOUARI \& ZOUALI, 1995; DERBALI et al.,. 2011; BELLAAJ-ZOUARI et al.,. 2012), Egypt (YASSIEN et al.,. 2000), Turkey (GOKOGLU et al.,. 2006) and Malta (DEIDUN et al.,. 2014).

In the Adriatic Sea, only few specimens were recorded up to date. VIO \& DE MIN (1996) described this species in Trieste Bay as live individuals attached to an oil platform originating from the Sicilian Channel. In the Gulf of Trieste, the species has never been recorded again and 
further researches in the area seem to confirm that it did not survive in the area (CROCETTA et al.,. 2009). Recently, two juvenile specimens (less than $3 \mathrm{~mm}$ in shell length) from $59 \mathrm{~m}$ on a siltysand bottom in the Croatian waters were identified as Pinctada radiata by DOĞAN \& NERLOVIĆ (2008). A very recent record from the Italian Adriatic Sea (Torre Guaceto) was also published (SCUDERI \& TERLIZZI, 2012).

Here we present the first record of $P$. radiata population from the Adriatic Sea as a basis for future monitoring of this species, listed as one of the 100 worst invasives (STREFTARIS \& ZENETOS, 2006).

\section{MATERIALS AND METHODS}

Research was performed in Porto Montenegro marina (Tivat, Montenegro) (Fig. 1) as a part of Biological monitoring program, in August 2016. Fouling material from the piers was surveyed and photographed by SCUBA diving, while some organisms were collected for further analysis in laboratory. In the holes between the concrete blocks of the pier, at $5 \mathrm{~m}$ depths, 15 randomly selected individuals of $P$. radiata were collected. Measurements were taken using an electronic digital calliper (precision of $0.01 \mathrm{~mm}$ ) so that comprised shell height (SH), shell length (SL), hinge length (HL) and shell width (SW) were measured. The material was preserved in $70 \%$ ethanol.

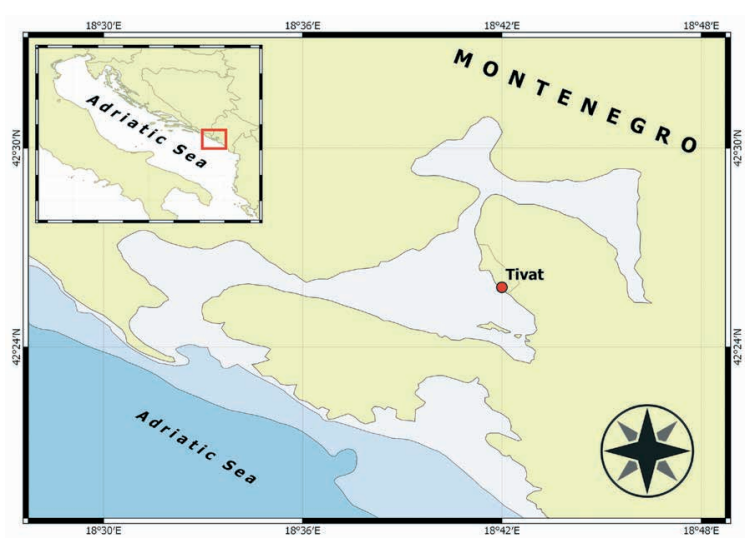

Fig. 1. Sampling location of P. radiata in Porto Montenegro marina (Tivat, Montenegro)

\section{RESULTS AND DISCUSSION}

This record of $P$. radiata is the first one for the south Adriatic and first data about large population in the Adriatic Sea. Values for the shell height (SH) ranged between $32 \mathrm{~mm}$ and $52 \mathrm{~mm}$ with an average SH value of $38.3 \mathrm{~mm}$ (standard deviation $\pm 6,1$ ) (Table1). Similar individual size is also found in Maltese island (DEIDUN et al., 2014), while a maximum value reported from other central Mediterranean localities, including Linosa $78.7 \mathrm{~mm}$ (LODOLA et al.,. 2013), El Bibane Lagoon in Tunisia $85.0 \mathrm{~mm}$ (SEURAT, 1929), Bizerte Lagoon in Tunisia $100.5 \mathrm{~mm}$ (TLIG-ZOUARI et al.,. 2010), Hammamet in Tunisia $104.3 \mathrm{~mm}$ (BELLAAJ-ZOUARI et al.,. 2012) and the Gulf of Gabes in Tunisia $96.0 \mathrm{~mm}$ (DERBALI et al.,. 2011) is markedly different.

Table 1. Biometric parameters of the P. radiata specimens sampled in Porto Montenegro marina, Montenegro

\begin{tabular}{cc}
\hline Biometric parameters & $\begin{array}{c}\text { Mean values } \\
( \pm \text { st dev in mm) }\end{array}$ \\
\hline Shell length (SL) & $38.3( \pm 7.3)$ \\
Hinge length (HL) & $39.7( \pm 5.3)$ \\
Shell height (SH) & $38.3( \pm 6.1)$ \\
Shell width (SW) & $11.4( \pm 2.1)$
\end{tabular}

Studying spatial patterns of marine alien species across the Ionian-Adriatic boundary, KATSANEVAKIS et al.,. (2011) found one $P$. radiata alive in the north part of Ionian Sea at only a single site (Saranda, Albania). Our record of new population in the south Adriatic Sea, together with the global warming signals (COLL et al.,. 2010), looks like spreading on the north, as a result of natural dispersal via larval transport by currents, but we should also have in mind possible dispersal by fouling. Interesting is also that $P$. radiata was found in Porto Montenegro marina only on newly constructed parts of the pier 1 (constructed in 2015), confirming its high ability in competition for space with native species (Fig. 2).

Because of its adaptation to subtropical environment and tolerance to chemical contami- 

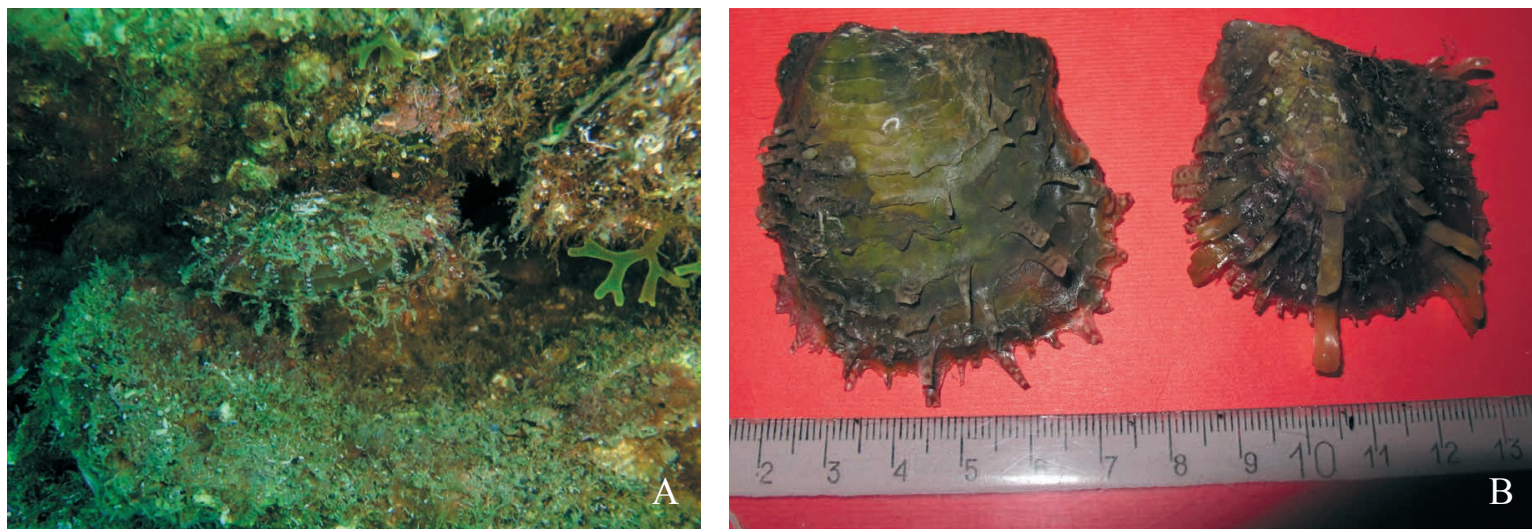

Fig. 2. Pictada radiata in situ $(A)$ and bivalve collected for morphometric analyses $(B)$

nation (KATSANEVAKIS et al.,. 2008) it is to expect that this population will survive. Our findings justify the setting up of a monitoring program in Porto Montenegro marina, while further surveys will provide more accurate information on its abundance, distribution in marina (and possibly in the surrounding) as well as possible impact on native biodiversity.

\section{ACKNOWLEDGEMENTS}

The study was carried out within the framework of the 2016/2017 biological monitoring program financed by Porto Montenegro Marina, Adriatic Marinas.

\section{REFERENCES}

BELLAAJ-ZOUARI, A., S. DKHILI, R. GHARSALLI, A. DERBALI \& N. ALOUI-BEJAOU. 2012. Shell morphology and relative growth variability of the invasive pearl oyster Pinctada radiata in coastal Tunisia. J. Mar. Biol. Assoc. U.K, 92(3): 553-563.

COLL, M., C. PIRODDI, J. STEENBEEK, K. KASCHNER, , LASRAM, FBR, AGUZZI, J., BALLESTEROS, C., BIANCHI, N., CORBERA, J., DAILIANIS, T. et al.,. 2010. The Biodiversity of the Mediterranean Sea: Estimates, Patterns, and Threats. PLoS ONE 5:e11842.

CROCETTA, F, W. RENDA W. \& A. VAZZANA. 2009. Alien Mollusca along the Calabrian shores of the Messina Strait area and a review of their distribution in the Italian Seas. Boll
Malacol 45: 15-30.

ÇEVIK, C., A. DOĞAN, M. ÖNEN \& A. ZENETOS. 2005. First record of the Indo-Pacific species Electroma vexillum (Mollusca: Bivalvia: Pterioida) in the eastern Mediterranean. JMBA2 - Biodiversity Records. doi:10.1017/ S002531540501213X

DEIDUN, A., F. GIANNI, D.P. CILIA, A. LODOLA \& D. SAVINI. 2014. Morphometric analyses of a Pinctada radiata (Leach, 1814) (Bivalvia: Pteriidae) population in the Maltese Islands. J Black Sea/Mediterranean Environment 20(1): 1-12.

DERBALI, A., O. JARBOUI, \& M. GHORBEL. 2011. Distribution, abundance and population structure of Pinctada radiata (Mollusca: Bivalvia) in southern Tunisian waters (Central Mediterranean). Cah Biol Mar 52: 23-31.

DOĞAN, A. \& V. NERLOVIĆ. 2008. On the occurrence of Pinctada radiata (Mollusca: Bivalvia: Pteriidae), an alien species in Croatian waters. Acta Adriatica 49 (2): 155-158.

GOKOGLU, N., M. GOKOGLU. \& P. YERLIKAYA. 2006. Seasonal variations in proximate and elemental composition of pearl oyster (Pinctada radiata, Leach, 1814). J. Sci. Food Agric. 86: 2161-2165.

KATSANEVAKIS, S., E. LEFKADITOU, S. GALINOUMITSOUDI, D. KOUTSOUBAS \& A. ZENETOS. 2008. Molluscan species of minor commercial interest in Hellenic Seas: distribution, exploitation and conservation status. Med Mar Sci 9:77-118. 
KATSANEVAKIS, S., A. ZENETOS, V. MAČIĆ, S. BEQIRAJ. \& D. POURSANIDIS. 2011. Invading the Adriatic: spatial patterns of marine alien species across the Ionian-Adriatic boundary. Aquat. Biol., 13:107-118.

LODOLA, A., L. NICOLINI, D. SAVINI, A. DEIDUN. \& A. OCCHIPINTI-AMBROGI. 2013. Range expansion and biometric features of Pinctada imbricata radiata (Bivalvia: Pteriidae) around Linosa Island, Central Mediterranean Sea (Italy). Ital J Zool 80(2), 303-312.

MONTEROSATO, T.A. 1878. Enumerazione e sinonimia delle conchiglie mediterranee. Giornale di Scienze Naturali ed Economiche di Palermo 13:61-115.

SEURAT, L.G. 1929. Observations sur les limites, les faciès et les associations animales de l'étage intercortidal de la petite Syrte (Golfe de Gabès). B. Inst. Nat. Sci. Tec. Mer. Salammbô 3:1-71.

SCUDERI, D. \& A. TERLIZZI 2012. Manuale di Malacologia dell'Alto Jonio. Lecce: Edizioni Grifo, 188 pp. in STASOLA, G., RIOLO, F., MACALI, A., PIERRI, C. \& F. CROCETTA. 2014. Further spreading in the Italian seas of already established non-indigenous mollusk species. Marine Biodiversity Records, Vol. 7: 1-8.

STREFTARIS, N. \& A. ZENETOS. 2006. Alien marine species in the Mediterranean- the 100 "Worst Invasives" and their impact. Med Mar Sci 7(1):87-118.

TLIG-ZOUARI, S., L. RABAOUI, I. IRATHNI, M., DIAWARA \& O. K. BEN HASSINE. 2010. Com- parative morphometric study of the invasive pearl oyster Pinctada radiata along the Tunisian coastline. Biol 65(2): 294-300.

TLIG-ZOUARI, S. \& J. ZAOUALI. 1995. La population de Pinctada radiata des îles Kerkennah (Tunisie). Paramètres démographiques et croissance. B Soc Sci Nat Tun 24: 103-117.

VIO, E. \& R. DE MIN. 1996. Contributo alla conoscenza dei Molluschi marini del Golfo di Trieste. Atti Mus Civ Stor Nat Trieste 47: $173-233$

WADA, K.T. \& I. TËMKIN. 2008. Taxonomy and phylogeny. In: Southgate P C, Lucas J S. (Editors). Elsevier, Philadelphia, USA., p. 37-75.

YASSIEN, M.H., F. A. ABD EL-RAZEK \& R. KILADA. 2000. Growth estimates of the Pearl Oyster, Pinctada radiata, from the eastern Mediterranean. Egypt J Aq Biol Fish 4:105-118.

ZENETOS, A., S. GOFAS, G., RUSSO \& J. TEMPLADO. 2003. CIESM Atlas of Exotic Species in the Mediterranean. Vol. 3. Molluscs. In: F. Briand (Editor). CIESM Publishers, Monaco, $376 \mathrm{pp}$.

ZENETOS, A., S. GOFAS, M. VERLAQUE, M.E. INAR, J.E. GARCIA RASO, C.N. BIANCHI, C. MORRI, E. AZZURRO, M. BILECENOGLU, C. FROGLIA. 2010. Alien species in the Mediterranean Sea by 2010 . A contribution to the application of European Union's Marine Strategy Framework Directive (MSFD). Part I. Spatial distribution. Med Mar Sci 11(2): 381-493.

Received: 12 December 2016

Accepted: 26 July 2017 


\title{
Novi podaci o vrsti Pinctada radiata (Leach, 1814) (Bivalvia: Pteriidae) u Jadranskom moru
}

\author{
Slavica PETOVIĆ* i Vesna MAČIĆ \\ *Kontakt e-adresa: kascelanslavica@gmail.com
}

\begin{abstract}
SAŽETAK
Prvi nalazi populacije Pinctada radiata u Jadranskom moru se odnose na dokove marine Porto Montenegro (Tivat, Crna Gora), u kolovozu 2016. godine. Na zidovima dokova zabilježene su brojne jedinke na dubini od $5 \mathrm{~m}$. Visina ljušture $(\mathrm{SH})$ za 15 slučajno odabranih jedinki $P$. radiata je kolebala od $32.2 \mathrm{~mm}$ do $52.1 \mathrm{~mm}$ sa srednjom vrijednošću od $38.3 \mathrm{~mm}$ (stand. dev. \pm 6.1 ). Daljna istraživanja u Crnoj Gori će omogućiti informacije o uspješnosti uspostavljanja ove populacije i njenom uticaju na lokalnu bioraznolikost.
\end{abstract}

Ključne riječi: unsene vrste, Pinctada radiata, morfometrijski parametri, Jadransko more 
